RESEARCH REPORT

\title{
Increasing ethnic differences in mortality in Estonia after the collapse of the Soviet Union
}

\author{
Mall Leinsalu, Denny Vågerö, Anton E Kunst
}

J Epidemiol Community Health 2004;58:583-589. doi: 10.1136/jech.2003.013755

See end of article for authors' affiliations

.....................

Correspondence to: Dr M Leinsalu, Stockholm Centre on Health of Societies in Transition, University College of South Stockholm, 14189 Huddinge, Sweden; Mall.Leinsalu@sh.se

Accepted for publication 17 October 2003

\begin{abstract}
Study objective: This study examined the change in ethnic differences in mortality in Estonia 1989-2000. Design: Two unlinked cross sectional census based analyses were compared. Total and cause specific mortality was analysed for ethnic Estonians and Russians. The absolute differences in mortality were evaluated through life expectancy at birth and age standardised mortality rates. Relative differences were assessed by mortality rate ratios with $95 \%$ confidence intervals, calculated using Poisson regression.

Setting: Estonia before and after the fall of the Soviet Union.

Participants: Individual cause specific death data for 1987-1990 (69 549 deaths) and for 1999-2000 (33 809 deaths) came from the national mortality database. Population denominators came from the population censuses of 1989 and 2000.

Main results: In the period 1989-2000, ethnic differences in life expectancy increased from 0.4 years to 6.1 years among men and from 0.6 years to 3.5 years among women. In 2000, Russians had a higher mortality than Estonians in all age groups and for almost all selected causes of death. The largest differences were found for some alcohol related causes of death especially in 2000.

Conclusions: Political and economic upheaval, increasing poverty, and alcohol consumption can be considered the main underlying causes of the widening ethnic mortality gap.
\end{abstract}


Table 1 Correspondence of selected causes of death in 1987-1990 (ICD-9) and in 1999-2000 (ICD-10)

\begin{tabular}{lll}
\hline Cause of death & $1987-1990$ ICD-9 & 1999-2000 ICD-10 \\
\hline Infectious diseases & $001-139$ & A00-B99 \\
Stomach cancer & 151 & Cl6 \\
Lung cancer & 162 & C33-C34 \\
Breast cancer & $174-175$ & C50 \\
Ischaemic heart disease & $410-414$ & $120-125$ \\
Cerebrovascular disease & $430-438$ & $160-169$ \\
Influenza and pneumonia & $487 ; 480-486$ & J10-J18 \\
Chronic respiratory disease & $490-494 ; 496$ & J40-J47 \\
Alcoholic liver cirrhosis & $571.0-571.3$ & K70 \\
Transport accidents & E800-E848 & V01-V99 \\
Alcohol poisoning & E860 & X45 \\
Suicide & E950-E959 & X60-X84 \\
Homicide & E960-E978 & X85-Y09, Y35, Y36 \\
\hline
\end{tabular}

adjusted (five year groups) mortality rate ratios with 95\% confidence intervals, using Poisson regression.

\section{RESULTS}

In 1989, ethnic differences in total mortality for all ages combined were small and statistically not significant (table 2). However, in the youngest age group Russians had significantly lower mortality than Estonians. This advantage decreased with each successive age group. From age 40-54 (that is, those born before 1949), Russians had higher mortality than Estonians. Cause specific data show a specific pattern (table 3). Russians had significantly higher mortality from stomach and lung cancer, chronic respiratory diseases, alcohol poisoning, and homicide, and significantly lower mortality from infectious diseases, ischaemic heart diseases (IHD) (men only), and transport accidents (men only).

By 2000, the ethnic differences in all cause mortality had changed remarkably. Total mortality for all ages combined had fallen 4\% among Estonian men and $11 \%$ among Estonian women. Among Russians the mortality rate had increased by $24 \%$ for men and by $1 \%$ for women (calculated from table 2 ). Russians had a higher mortality than Estonians in all age groups. Relative mortality differences had increased sharpest among those aged 25-39. As a result, in the period 19892000, Estonians' advantage in life expectancy increased from 0.4 years to 6.1 years among men and from 0.6 years to 3.5 years among women (fig 1).

Russians had higher mortality than ethnic Estonians for almost all causes of death in 2000 (table 3). Except for stomach and lung cancer, chronic respiratory diseases, and transport accidents, the mortality trends had been invariably less favourable for Russians. For IHD mortality the ethnic pattern among men was reversed as a result of decreasing mortality among Estonians and slightly increasing mortality

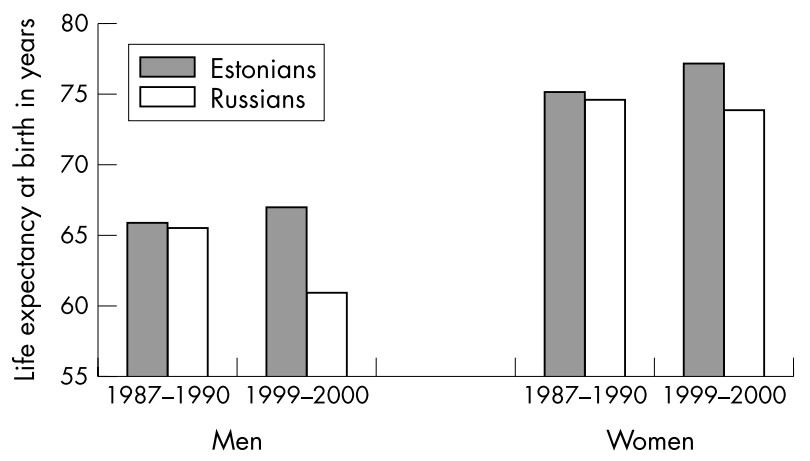

Figure 1 Average life expectancy at birth by ethnicity in Estonia. among Russians. In 2000, the relative ethnic differences were largest for alcoholic liver cirrhosis, alcohol poisoning, homicide, and influenza and pneumonia.

\section{DISCUSSION}

Political and economic restructuring in Estonia in the early 1990s changed fundamentally the societal position of its two main ethnic groups. It seems that these societal changes had large, but very different, effects on their mortality. The several causes of death involved in the widening of the Estonian-Russian mortality gap suggest a diversity of causal mechanisms.

\section{Methodological considerations}

In unlinked, census based mortality analysis the results may be biased if the mortality database and the census database do not correspond. For 1987-1990 the ethnicity on the deceased's passport was used on death certificates, whereas on census records ethnicity was self reported. As other Russian speaking ethnic groups such as Ukrainians and Belorussians could more easily report themselves at census as being Russian, ${ }^{13}$ the mortality estimates for Russians for 1987-1990 could be slightly underestimated. The number of cases where ethnicity was not registered had increased in $1999-2000$ to $0.6 \%$ of all census records and $1.2 \%$ of all deaths. The latter concerns mostly unidentified persons who had died from external causes. Violent deaths were more common among Russians, and their mortality rate may therefore also be slightly underestimated for 1999-2000. According to the Estonian Statistical Office, census nonresponse was not overwhelmingly prevalent among any specific ethnic group. On balance, a strong numerator/ denominator bias in trend estimates is unlikely.

For some causes of death, small numbers make mortality estimates prone to large random fluctuations. Change from ICD-9 to ICD-10 may have affected cause specific mortality trends, but such a bias is unlikely to have affected different ethnic groups in different ways.

In Estonia, 93\% of Russians but only 56\% of ethnic Estonians live in the cities. ${ }^{12}$ As the mortality in rural areas is higher than in the cities, ${ }^{20}$ the control for residence (which we could not carry out) would most probably increase the mortality difference between Estonians and Russians, which would support our main conclusion.

From 1989 to 2000 the Russian population in Estonia decreased by $26 \%{ }^{12}$ The decrease was greatest in age groups $0-9$, largely reflecting sharply diminished birth rates, and in age groups 25-39, mostly because of re-migration. ${ }^{21}$ It is probable that migration was higher among graduates, which partly explains the decrease in the proportion of university 


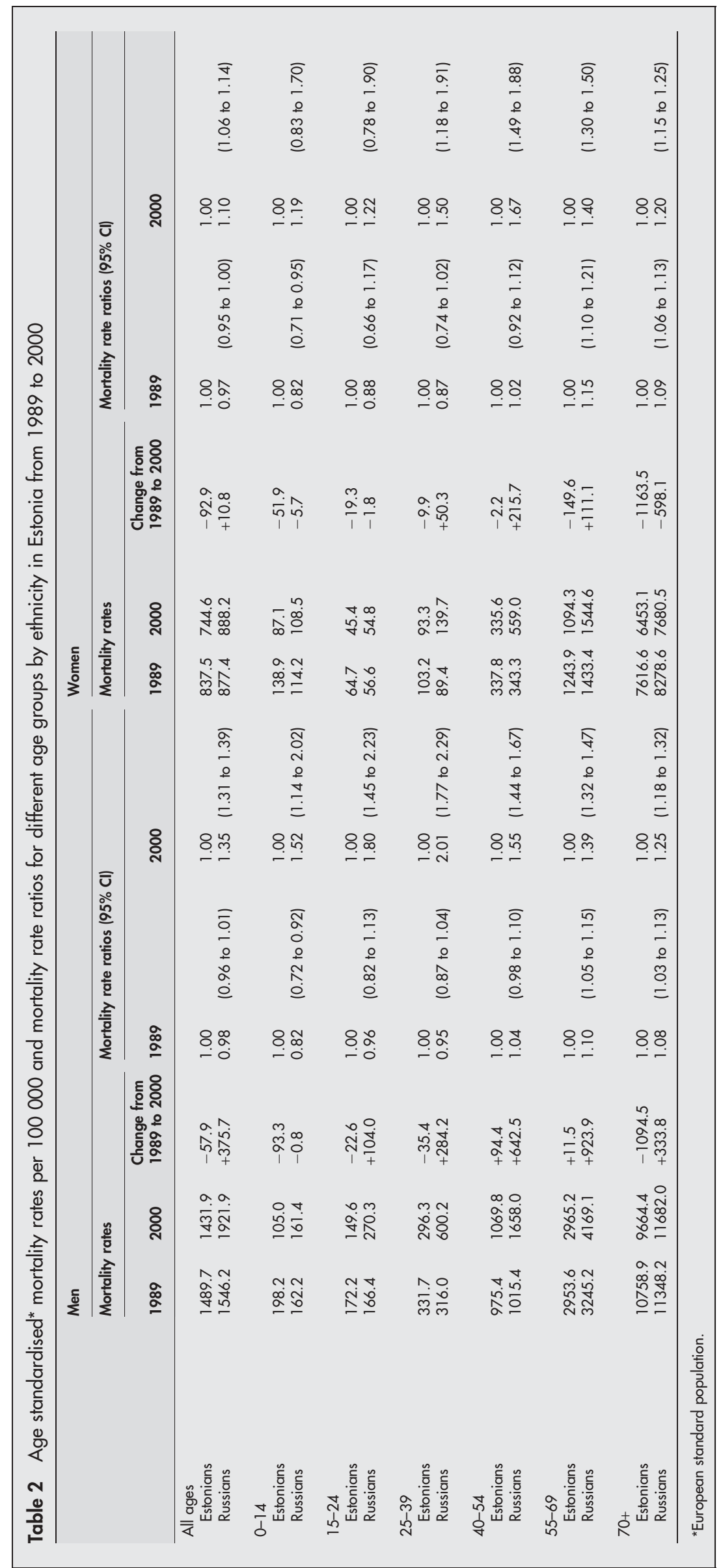




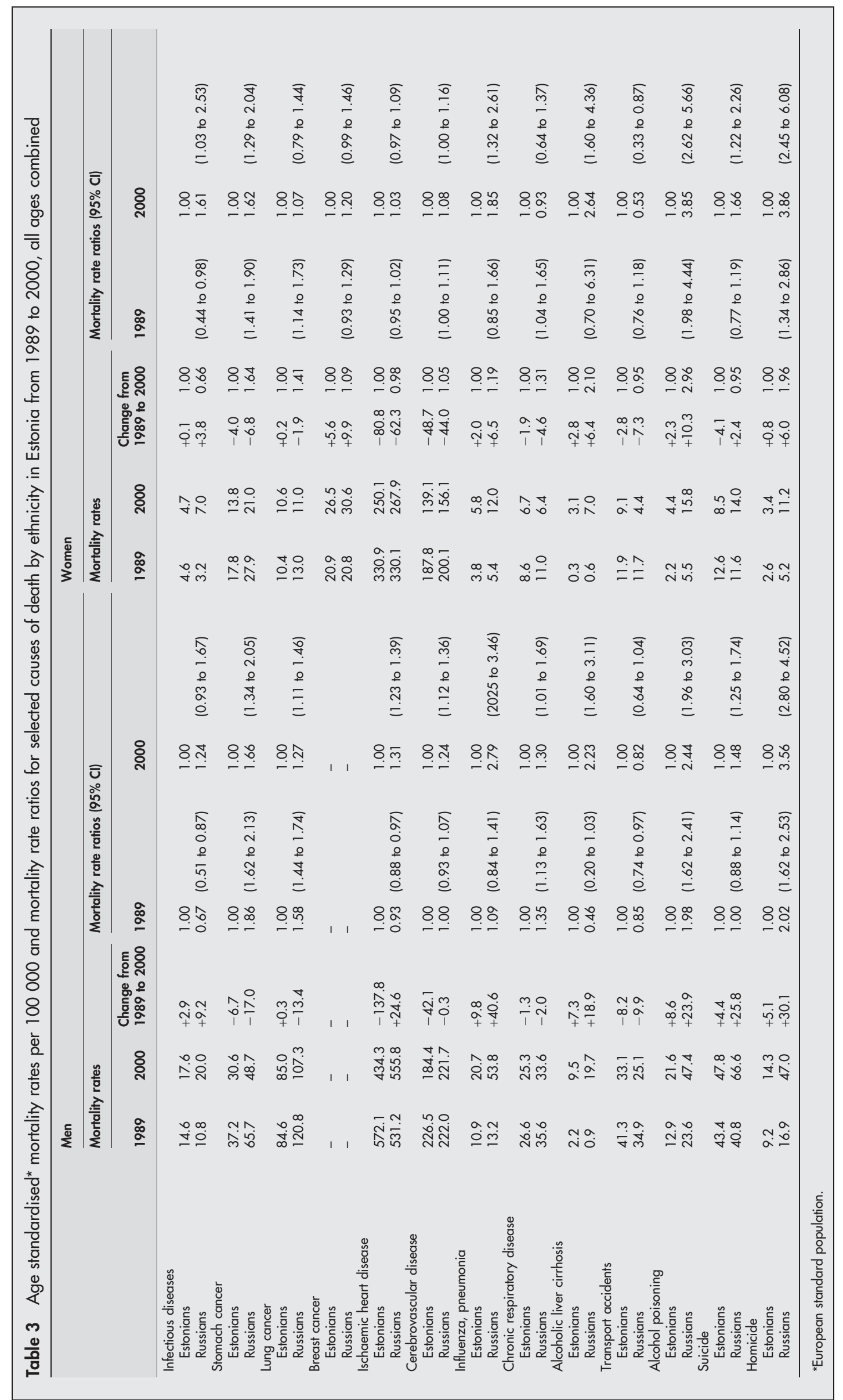


educated men among young Russians from 1989 to 2000 (table 4). Educational differences in mortality are growing in Estonia, ${ }^{10}$ and may contribute to growing ethnic differences in mortality among 25-39 year old men. However, in 1989 (men and women) and in 2000 (men), the average percentage of university educated persons was somewhat higher among Russians than ethnic Estonians.

Therefore, it seems fair to conclude that cause specific mortality differences and the increasing Estonian-Russian mortality gap are neither attributable to bias, nor to confounding from residence, nor largely mediated by education.

\section{Historical context-political and economic restructuring}

Protestantism and almost total literacy by the end of the 19th century $^{13}$ had supported a modern development and the gradual implementation of Western democratic values in Estonia between 1918 and 1940. During the Soviet annexation, ethnic Estonians maintained their cultural identity with the West, whereas the immigrant populations, both Russian and non-Russian, were predominantly oriented towards the Soviet Union. The restoration of Estonian statehood deeply touched the identity and values of Russians, who, as former representatives of the major nation in the Soviet Union, lost their social standing. Their adaptation to Estonia's liberal free market reforms was difficult and reluctant. In addition, Estonia adopted a citizenship policy that granted citizenship to the citizens of the pre-occupation republic and their descendants; Soviet era immigrants had to fulfil naturalisation requirements. ${ }^{22}$ In 2000, only $40 \%$ of Russians had Estonian citizenship. ${ }^{12}$ As a result, large sections of the nonEstonian population saw themselves as socially excluded.

Most Russians arrived in Estonia during the forced Soviet industrialisation programme. Their working lives were closely linked to large all union industrial enterprises. Their skills were dominated by technical and vocational education, mainly related to this industry. ${ }^{23}$ With the fall of the Soviet Union, these enterprises lost their traditional markets. NonEstonians have had a stable six percentage points higher unemployment rate than Estonians since 1995. ${ }^{24}$ Inadequate skills in the Estonian language also hindered Russians from returning to employment. ${ }^{15}$ Consequently, non-Estonians faced a strong reduction in relative wages compared with Estonians. ${ }^{25}{ }^{26}$ For the younger generation access to higher education in the Russian language has become more limited. Restitution of properties nationalised by the Soviet regime in 1940 also reallocated economic resources. ${ }^{27}$

\section{Key points}

- Ethnic differences in mortality increased in Estonia from 1989 to 2000.

- In 2000, Russians had higher mortality than Estonians for all age groups and for almost all selected causes of death.

- Political and economic upheaval, increasing poverty, and alcohol consumption can be considered the main underlying causes of the widening mortality gap.

\section{Mediating mechanisms \\ Poverty}

Poverty is likely to affect many causes of death ${ }^{28}$ through its impact on living conditions, diet, behaviours such as smoking, alcohol drinking, and violence, and psychological factors such as depression. In 1999, 15.6\% of non-Estonian households had incomes below the poverty line $(60 \%$ of median income) whereas the corresponding percentage for households with an Estonian head was $11.3 \%{ }^{24}$ Sharply increased mortality from infectious diseases from 1989 to 2000 provides evidence of poverty driven causal mechanisms. In 1989, ethnic Estonians had a higher mortality from infectious diseases than Russians, but because of the more rapid mortality increase among Russians during the 1990s, the mortality pattern for infectious diseases was reversed by 2000. The relation between poverty and cardiovascular disease is more unclear.

\section{Alcohol}

Alcohol is considered one of the main determinants of the mortality crisis in Russia. ${ }^{29}$ In 1989, mortality from alcohol poisoning and homicide (the second factor also directly linked to alcohol consumption) was two to three times higher among Russian men and women in Estonia than among ethnic Estonians. The high mortality rate for alcohol poisoning but very low mortality from liver cirrhosis in 1989 indicates that binge drinking rather than the accumulated exposure to alcohol over the years was the problem among Russian men at this time. Survey data show that Russian men are more likely to binge drink $(70+\mathrm{g}$ pure alcohol on one occasion) while Estonian men tend to drink more frequently. ${ }^{30}$ Binge drinking may increase the risk of cardiovascular mortality, ${ }^{31}$ but in 1989 Russian men were not more likely to die from ischaemic heart disease or stroke than Estonian men.

Table 4 Percentage of population with university education in different age groups by ethnicity in Estonia in 1989 and 2000

\begin{tabular}{|c|c|c|c|c|}
\hline & \multicolumn{2}{|l|}{1989} & \multicolumn{2}{|l|}{2000} \\
\hline & Estonians & Russians & Estonians & Russians \\
\hline \multicolumn{5}{|l|}{ Men } \\
\hline 25-39 & 15.5 & 17.9 & 15.1 & 12.8 \\
\hline $40-54$ & 14.9 & 17.3 & 18.0 & 19.1 \\
\hline $55-69$ & 10.9 & 11.3 & 16.3 & 16.8 \\
\hline $70+$ & 4.8 & 10.4 & 11.4 & 13.4 \\
\hline Total & 13.2 & 16.2 & 15.9 & 16.0 \\
\hline \multicolumn{5}{|l|}{ Women } \\
\hline $25-39$ & 20.9 & 19.7 & 21.3 & 19.2 \\
\hline $40-54$ & 16.9 & 15.7 & 22.3 & 21.4 \\
\hline $55-69$ & 7.8 & 7.9 & 15.8 & 14.1 \\
\hline $70+$ & 1.6 & 3.2 & 5.9 & 7.4 \\
\hline Total & 12.7 & 14.2 & 17.1 & 16.8 \\
\hline
\end{tabular}


Between 1989 and 2000, mortality from alcohol poisoning, alcoholic liver cirrhosis, homicide, influenza and pneumonia increased for Estonians and Russians, but the increase was considerably higher among Russians. This suggests that increasing alcohol consumption 1989-2000 contributed firstly to the poor mortality trend of the 1990s in Estonia, and secondly to the widening mortality gap between Estonians and Russians. Binge drinking may in particular have contributed to the trend of increasing IHD and total mortality among Russian men 1989-2000.

\section{Tobacco}

Smoking is the main determinant of lung cancer and chronic respiratory disease mortality and is an important risk factor for cardiovascular mortality. ${ }^{32}$ In 1989, Russian men and women had much higher lung cancer mortality and chronic respiratory disease mortality than Estonians. From 1989 to 2000 the trends for lung cancer mortality and chronic respiratory disease mortality rates were more favourable for Russians (falling).

In 1996/1997, in the age group 60-79, Russian men had almost two times higher odds for ever having smoked than Estonian men, whereas this difference was smaller and statistically not significant in younger age groups. ${ }^{30}$ This age specific smoking pattern explains the higher lung cancer and chronic respiratory disease mortality for Russian men and may have contributed to the narrowing mortality gap from these causes in the 1990s. The excess lung cancer mortality among Russian women in 1989 is more difficult to interpret, because the prevalence of those who have "ever smoked" is higher for elderly Estonian women. ${ }^{30}$ As the smoking prevalence among women in old age is small, the bigger impact of passive smoking among Russian women could contribute to their higher lung cancer mortality. It is unlikely that tobacco contributed to the unfavourable mortality trends for the Russians in the 1990s.

The differential exposure to air pollution from industrial sources could contribute to the different lung cancer rates and trends. Most Russians live in industrial regions that are more exposed to air pollution. In 1990-1998, the air pollution from stationary sources fell by $64 \%$ in Estonia, ${ }^{33}$ and Russians benefited more from this improvement.

\section{Diet}

Poor nutrition is likely to explain part of the East-West cardiovascular mortality divide in Europe. ${ }^{31} 34$ In Estonia, cardiovascular disease mortality and particularly IHD mortality, has been very high: in 1989 IHD mortality in Estonia was twice that in Sweden and 30\% higher than in Russia. ${ }^{35}$ From 1989 to 2000 IHD mortality rates fell by a fifth in Estonia. Data comparing 1984 and 1993 show a major change in diet, measured as lower intake of energy, animal protein, fat, saturated fatty acids, and cholesterol and higher consumption of vegetable protein. This would have helped the overall decline in cardiovascular mortality. ${ }^{36}$ In the mid1980s, Estonian men had more "atherogenic" nutrition habits and serum lipoprotein profile than Russian men. ${ }^{37}$ The higher IHD mortality among Estonian than among Russian men in 1989 could at least partly be related to their poorer dietary habits. During the 1990s, vegetable consumption was higher among Russians, however the increase in consumption over the decade was faster for Estonians, ${ }^{20}$ thereby contributing to their more rapid fall in cardiovascular mortality.

\section{Other factors}

Psychological factors such as depression are suggested as independent risk factors for coronary heart disease and stroke. ${ }^{38}$ In the mid-1990s, Russians reported more depressive symptoms than ethnic Estonians $(\mathrm{OR}=1.80) .{ }^{39}$ The increased suicide rate among Russian men indicates that the adaptation to a new social and political order has been particularly difficult for this group of men.

A number of studies have suggested that adverse conditions in early life create vulnerability, and therefore interact with later life conditions. ${ }^{40}{ }^{41}$ In 1989, 57\% of Russians were born outside Estonia. ${ }^{42}$ Russians aged 40 and over had a higher mortality than ethnic Estonians in the same age group. Stomach cancer mortality, suggested to be related to adverse childhood conditions ${ }^{43}$ is considerably higher among Russians, probably explained by the lower housing standards in Russia at the time of their birth. Adverse childhood conditions may have influenced ethnic differences in mortality in Estonia by making the Russian population more vulnerable to sudden social changes in the 1990s.

\section{Conclusions}

Political and economic restructuring in Estonia has had profound, but different, effects on its two main ethnic groups. This study revealed a remarkable increase in mortality differences between Estonians and Russians. We could not address directly questions of underlying causal pathways. However, we suggest that future researchers should focus on differences in deprivation, on social exclusion, and the response to social change, including diet, alcohol, and other health related behaviours. The successful integration of the Russian population in Estonia could be an important step towards the further improvement of the overall health status in the country.

\section{ACKNOWLEDGEMENTS}

We thank five anonymous referees for their comments.

\section{Authors' affiliations}

M Leinsalu, Stockholm Centre on Health of Societies in Transition, University College of South Stockholm (Södertörn), Huddinge, Sweden D Vågerö, Centre for Health Equity Studies, CHESS, Stockholm University/Karolinska Institute, Stockholm, Sweden

A E Kunst, Department of Public Health, Erasmus MC, University Medical Centre, Rotterdam, Netherlands

Funding: This study was supported by the Swedish Foundation for Baltic and East European Studies (project grant "Social and public health developments in Eastern Europe"), and by a grant from the Ministry of Social Affairs of Estonia/the World Bank.

Conflicts of interest: none declared.

\section{REFERENCES}

1 Chaturvedi N. Ethnicity as an epidemiological determinant - crudely racist or crucially important? Int J Epidemiol 2001;30:925-7.

2 Kiefe Cl. Race/ethnicity and cancer survival. The elusive target of biological differences. JAMA 2002;287:2138-9.

3 Kaufman JS, Cooper RS. Commentary: considerations for use of racial/ethnic classification in etiologic research. Am J Epidemiol 2001;154:291-8.

4 Williams DR. Race and health: basic questions, emerging directions. Ann Epidemiol 1997;7:322-33.

5 Davey Smith G. Learning to live with complexity: ethnicity, socioeconomic position, and health in Britain and the United States. Am J Public Health 2000;90:1694-8.

6 Thomas SB. The color line: race matters in the elimination of health disparities. Am J Public Health 2001;91:1046-9.

7 Valkonen T. Male mortality from ischaemic heart disease in Finland: relation to region of birth and region of residence. Eur J Popul 1987;3:61-83.

8 Vågerö D. Region of birth and mortality among Black Americans. Am J Public Health 1997;87:724-6.

9 Cornia GA, Paniccià R, eds. The mortality crisis in transitional economies. Oxford: Oxford University Press, 2000:456.

10 Leinsalu M, Vågerö D, Kunst A. Estonia 1989-2000: enormous increase in mortality differences by education. Int J Epidemiol 2003;32:1081-7.

11 Shkolnikov VM, Leon DA, Adamets S, et al. Educational level and adult mortality in Russia: an analysis of routine data 1979 to 1994. Soc Sci Med 1998;47:357-69.

12 Statistical Office of Estonia. Population and housing census 2000.II. Citizenship, nationality, mother tongue and command of foreign languages. Tallinn: Statistical Office of Estonia, 2001:348. 
13 Raun TU. Estonia and the Estonians. Studies of nationalities of the USSR. 2nd edn. Stanford: Hoover Institution Press, 1991:336.

14 Misiunas RJ, Taagepera R. The Baltic States: years of dependence 19401990. London: Hurst, 1993:400.

15 Vodopivec $M$. Worker reallocation during Estonia's transition to market. International Journal of Manpower 2002;23:77-97.

16 Katus K, Puur A. Eesti rahvastiku suremusest elutabelite analüüsi põhjal. Akadeemia 1991;3:2516-49.

17 Krūminš J, Usackis U. The mortality consequences of the transition to market economy in Latvia, 1991-1995. In: Cornia GA, Paniccia R, eds. The mortality crisis in transitional economies. Oxford: Oxford University Press, 2000:280-302.

18 Statistical Office of Estonia. Population 1999. Tallinn: Statistical Office of Estonia, 2000:109.

19 State Committee of Statistics of the USSR. The short list of causes of death for 1981, based on the Ninth Revision of the International Classification of Diseases, Injuries and Causes of Death from 1975. [In Russian]. Moscow: State Committee of Statistics of the USSR, 1980.

20 Kunst AE, Leinsalu M. Habicht J, et al. Social inequalities in health in Estonia. Technical document. Tallinn: Ministry of Social Affairs, 2002:320 (http:// www.sm.ee/gopro30/Web/gpweb.nsf/pages/indexeng.html).

21 Tammaru T, Kulu H. The ethnic minorities of Estonia: changing size, location and composition. Eurasian Geography and Economics 2003:44:105-20.

22 Pettai V, Hallik K. Understanding processes of ethnic control: segmentation, dependency and co-optation in post-communist Estonia. Nations and Nationalism 2002;8:505-29.

23 Pavelson $M$, Luuk M. Non-Estonians on the labour market: a change in the economic model and differences in social capital. In: Lauristin M, Heidmets $M$ eds. The challenge of the Russian minority. Emerging multicultural democracy in Estonia. Tartu: Tartu University Press, 2002:89-117.

24 Statistical Office of Estonia. Social trends 2. Tallinn: Statistical Office of Estonia, 2001:160.

25 Noorkõiv R, Orazem PF, Puur A, et al. Employment and wage dynamics in Estonia, 1989-95. Economics of Transition 1998;6:481-503.

26 Leinsalu $M$. Social variation in self-rated health in Estonia: a cross-sectional study. Soc Sci Med 2002;55:847-61

27 Andersen EA. The legal status of Russians in Estonian privatisation legislation 1989-1995. Europe-Asia Studies 1997:49:303-16.

28 Davey Smith G, Neaton JD, Wentworth D, et al. Socioeconomic differentials in mortality risk among men screened for the Multiple Risk Factor Intervention
Trial: Part I, results for 300,685 white men. Am J Public Health 1996;86:486-96.

29 Leon DA, Chenet L, Shkolnikov VM, et al. Huge variation in Russian mortality rates 1984-94: artefact, alcohol, or what? Lancet 1997:350:383-8.

30 Leinsalu M, Aluoja A, Noorkõiv R, et al. Sotsiaalmajanduslik kuuluvus ning selle toimemehhanismid vaimse ja fü̈usilise terviseseisundi määramisel, [Socioeconomic inequalities in physical and mental health and some possible explanatory mechanisms]. Project report. [In Estonian]. Tallinn: National Research and Development Program in Public Health, 2003.

31 McKee M, Shkolnikov V. Understanding the toll of premature death among men in Eastern Europe. BMJ 2001;323:1051-5.

32 Peto R, Lopez AD, Boreham J, et al. Mortality from smoking in developed countries 1950-2000. Oxford: Oxford University Press, 1994:553

33 Statistical Office of Estonia. Statistical Yearbook of Estonia 1999. Tallinn: Statistical Office of Estonia, 1999:383.

34 Bobak M, Skodova Z, Pisa Z, et al. Political changes and trends in cardiovascular risk factors in the Czech Republic, 1985-92. J Epidemiol Community Health 1997;51:272-7.

35 WHO. European health for all database (http://www.who.dk/hfadb)

36 Volozh O, Solodkaya E, Abina J, et al. Some biological cardiovascular risk factors and diet in samples of the male population of Tallinn, Estonia in 1984/ 1985 and 1992/1993. Eur J Public Health 2002;12:16-21.

37 Volozh O, Saava M, Tur I, et al. Ethnic differences in coronary heart disease risk factors in Estonia. Cardiovascular Risk Factors 1995:5:305-10.

38 Thomas AJ, Kalaria RN, O'Brien JT. Depression and vascular disease: what is the relationship? J Affect Disord 2004;79:81-95.

39 Aluoja A, Leinsalu M, Shlik J, et al. Symptoms of depression in the Estonian population: prevalence, sociodemographic correlates and social adjustment. $J$ Affect Disord 2004;78:27-35.

40 Leon DA, Koupilova I, Lithell HO, et al. Failure to realize growth potential in utero and adult obesity in relation to blood pressure in 50 year old Swedish men. BMJ 1996;312:401-6.

41 Modin B. Born out of wedlock and never married-it breaks a man's heart. Soc Sci Med 2003;57:487-501.

42 Statistical Office of Estonia. Population and housing census 2000.III. Place of birth and migration. Tallinn: Statistical Office of Estonia, 2002:306.

43 Leon DA, Davey Smith G. Infant mortality, stomach cancer, stroke, and coronary heart disease: ecological analysis. BMJ 2000;320:1705-6. 